\title{
An Impact Study-Perception and Constraints of Organic Agriculture Farmers
}

\author{
P. Namboothiripad ${ }^{1 *}$, J. Pushpa ${ }^{1}$, K. Mahandrakumar ${ }^{1}$, \\ J. S. Amarnath ${ }^{2}$ and K. Prabakaran ${ }^{2}$ \\ ${ }^{1}$ Department of .of Agricultural Extension and Rural Sociology, ${ }^{2}$ Department of .of \\ Agricultural Economics, Agricultural College and Research Institute, Tamilnadu Agricultural \\ University, Madurai, Tamilnadu, India \\ *Corresponding author
}

\section{A B S T R A C T}

\begin{tabular}{|c|}
\hline Keywords \\
\hline $\begin{array}{l}\text { Organic agriculture, } \\
\text { Perception, } \\
\text { Constraints, } \\
\text { Garretts ranking, } \\
\text { Weighted Mean } \\
\text { Score (WMS) }\end{array}$ \\
\hline Article Info \\
\hline $\begin{array}{l}\text { Accepted: } \\
15 \text { December } 2020 \\
\text { Available Online: } \\
10 \text { January } 2021\end{array}$ \\
\hline
\end{tabular}

\section{Keywords}

Organic agriculture, Perception,

Constraints

Garretts ranking, Weighted Mean

\section{Article Info}

Accepted: Available Online: 10 January 2021

\begin{abstract}
Abundant ecological changes and industrial developments result in an increasing artificial facilities and the impact of human activities leads to the demolition and loss of natural resources and its habitats. Organic agriculture is the method of food production using the naturally available resources particularly organic and by avoiding any type of artificially made chemicals, fertilizers, pesticides, fungicides, weedicide etc. Also to sustaining the ecosystem and pollution less agriculture production, there is a need of organic agriculture at present days. Tamil Nadu Agricultural University (TNAU) imparts training at every month on organic agriculture to the interested farmers. This study was conducted with a structured interview schedule with 200 trained farmers belongs to three districts of Tamilnadu namely Coimbator, Tiruppur and Krishnagiri. The study revealed that improvement of soil health followed by perception on domestic as well as commercial motive ranked first and second respectively with WMS of 4.82 and 4.67. The major constraints expressed by the organic agricultural farmers were less availability and high cost of input followed by insufficient premium price which ranked first and second respectively with the mean score of 62.40 and 60.34 respectively.
\end{abstract}

\section{Introduction}

As defined by International Federation of Organic Agriculture Movements (IFOAM), Organic agriculture is a production system that sustains the health of soils, ecosystems and people. It relies on ecological processes, biodiversity and cycles adapted to local conditions, rather than the use of inputs with adverse effects. Organic agriculture combines tradition, innovation and science to benefit the shared environment and promote fair relationships and a good quality of life for all involved.

India ranked $8^{\text {th }}$ with respect to the land of organic agriculture and $88^{\text {th }}$ in the ratio of organic crops to agricultural land as per Agricultural and Processed Food Products Export Development Authority and Report of 
Research Institute of Organic Agriculture. But a significant growth in the organic sector in India has been observed (Willer and Lernoud, 2017) in the last decades.

There have been about a threefold increase from 528171 ha in 2007-08 to 1.2 million ha of cultivable land in 2014-15. Associated Chambers of Commerce \& Industry in India, study found that the organic food turnover is increasing at about 25 per cent annually and thereby will be expected to reach USD 1.36 billion in 2020 from USD 0.36 billion in 2014 (Willer and Lernoud,2017).

The Consumption and popularity of organic foods are increasing day by day throughout the World. Indian traditional farmers possess a deep insight based on their Knowledge, extensive observation, perseverance and practices for maintaining soil fertility, and pest management which are found effective in strengthening organic production and subsequent economic growth in India. The progress in organic agriculture is quite commendable. Currently, India has become the largest organic producer in the globe (Willer and Lernoud, 2017, 2019) and ranked eighth having 1.78 million ha of organic agriculture land in the World in 2017 (Sharma and Goyal, 2000; Adolph and Butterworth, 2002; Willer and Lernoud, 2019). With the above context, this study was conducted with the specific objectives to find out the perception of organic agriculture and constraints of organic agriculture faced by the organic agriculture farmers.

\section{Materials and Methods}

This study involves the investigation of trainees participated in the Organic Agriculture Training Programme, organized by the Tamilnadu Agricultural University (TNAU), Coimbatore. So, the trainees from three districts viz., Coimbatore, Krishnagiri and Tiruppur in Tamil Nadu state were selected for this study based on the number of trainees participated ranked first, second and third respectively.

The lists of trainees were obtained from the Department of Sustainable Organic Agriculture, TNAU, Coimbatore. Total sample size was 200 trainees of organic agriculture. These 200 trainees were selected from three districts in proportionate allocation to the number of the trainees in each district using proportionate random sampling method.

To find out the perception of organic agriculture, ten statements were used by adopting the modified scale and scoring procedure developed by Supe (1969) with five point continnum scale as strongly agree (SA), agree (A), undecided (UD), disagree (DA) and strongly disagree (SDA) with the scores of five, four, three, two and one respectively. Weigted mean Score (WMS) was calculated for ranking the perception statements.

To find and ranking the constraints faced by the organic farmers, the respondents were asked to rank the prepared constraint statements. The collected rank details was used in the Garrett ranking technique to finalize the ranking order of the constraints.

\section{Results and Discussion}

\section{Perception organic agriculture}

There were 10 statements were projected about the organic agriculture to assess the perception level of organic farmers with five point continuum scale and weightage mean score was calculated and are presented in table 1 .

It could be observed from the table 1 that perception on improvement of soil health 
ranked first as per weighted mean score derived as 4.82 followed by perception on domestic as well as commercial motive weighted mean score of 4.67and use of indigenous knowledge ranked as third with the weighted mean score of 4.65.These might be due to the fact that plant nutrition depends on biologically derived nutrients instead of using readily soluble forms of nutrients. Bulky organic materials play a key role in suppressing weeds, pest and diseases which was experienced by majority of the respondents. Hence perception on improvement of soil health ranked first.
This finding is in conformity with the finding of Aulakh et al., (2009) reported that majority of the organic farmers were satisfied with organic farming mainly due to the perception that organic farming improves soil health.

Further, organic produce fetches high value and demand in the market and use of indigenous knowledge such as farmyard manure, oilcake, spraying of cow urine etc., which leads to reduce the use of chemicals in agriculture. Hence perception on domestic as well as commercial motive and use of indigenous knowledge ranked second and third respectively.

Table.1 Perception on Organic Agriculture ( $\mathrm{n}=200)$

\begin{tabular}{|c|c|c|c|c|c|c|c|c|c|}
\hline S.No & Particulars & SA & $\mathbf{A}$ & UD & DA & SDA & $\begin{array}{l}\text { Total } \\
\text { score }\end{array}$ & WMS & Rank \\
\hline 1. & $\begin{array}{l}\text { Improvement of } \\
\text { soil health in farm }\end{array}$ & $\begin{array}{l}165 \\
(82.5 \%)\end{array}$ & $\begin{array}{l}35 \\
(17.5 \%)\end{array}$ & $\begin{array}{l}0 \\
(0 \%)\end{array}$ & $\begin{array}{l}0 \\
(0 \%)\end{array}$ & $\begin{array}{l}0 \\
(0 \%)\end{array}$ & 965 & 4.82 & 1 \\
\hline 2. & $\begin{array}{l}\text { Sustain the farm } \\
\text { productivity }\end{array}$ & $\begin{array}{l}60 \\
(30.0 \%)\end{array}$ & $\begin{array}{l}112 \\
(56.0 \%)\end{array}$ & $\begin{array}{l}18 \\
(9.0 \%)\end{array}$ & $\begin{array}{l}8 \\
(4.0 \%)\end{array}$ & $\begin{array}{l}2 \\
(1.0 \%)\end{array}$ & 820 & 4.10 & 7 \\
\hline 3. & $\begin{array}{l}\text { For both } \\
\text { domestic and } \\
\text { commercial } \\
\text { motive }\end{array}$ & $\begin{array}{l}135 \\
(67.5 \%)\end{array}$ & $\begin{array}{l}65 \\
(32.5 \%)\end{array}$ & $\begin{array}{l}0 \\
(0 \%)\end{array}$ & $\begin{array}{l}0 \\
(0 \%)\end{array}$ & $\begin{array}{l}0 \\
(0 \%)\end{array}$ & 935 & 4.67 & 2 \\
\hline 4. & $\begin{array}{l}\text { Fetching high } \\
\text { price for produce }\end{array}$ & $\begin{array}{l}34 \\
(17.0 \%)\end{array}$ & $\begin{array}{l}86 \\
(43.0 \%)\end{array}$ & $\begin{array}{l}53 \\
(26.5 \%)\end{array}$ & $\begin{array}{l}22 \\
(11.0 \%)\end{array}$ & $\begin{array}{l}5 \\
(2.5 \%)\end{array}$ & 722 & 3.61 & 8 \\
\hline 5. & $\begin{array}{l}\text { Reduce high cost } \\
\text { of insecticide, } \\
\text { pesticide and } \\
\text { fertilizers }\end{array}$ & $\begin{array}{l}18 \\
(9.0 \%)\end{array}$ & $\begin{array}{l}90 \\
(45.0 \%)\end{array}$ & $\begin{array}{l}80 \\
(40.0 \%)\end{array}$ & $\begin{array}{l}12 \\
(6.0 \%)\end{array}$ & $\begin{array}{l}0 \\
(0 \%)\end{array}$ & 714 & 3.57 & 9 \\
\hline 6. & $\begin{array}{l}\text { Production of } \\
\text { quality produce }\end{array}$ & $\begin{array}{l}52 \\
(26.0 \%)\end{array}$ & $\begin{array}{l}143 \\
(71.5 \%)\end{array}$ & $\begin{array}{l}5 \\
(2.5 \%)\end{array}$ & $\begin{array}{l}0 \\
(0 \%)\end{array}$ & $\begin{array}{l}0 \\
(0 \%)\end{array}$ & 847 & 4.23 & 6 \\
\hline 7. & $\begin{array}{l}\text { Production of } \\
\text { chemical free } \\
\text { products }\end{array}$ & $\begin{array}{l}95 \\
(47.5 \%)\end{array}$ & $\begin{array}{l}95 \\
(47.5 \%)\end{array}$ & $\begin{array}{l}10 \\
(5.0 \%)\end{array}$ & $\begin{array}{l}0 \\
(0 \%)\end{array}$ & $\begin{array}{l}0 \\
(0 \%)\end{array}$ & 885 & 4.42 & 4 \\
\hline 8. & $\begin{array}{l}\text { Very difficult } \\
\text { supervision and } \\
\text { maintenance }\end{array}$ & $\begin{array}{l}45 \\
(22.5 \%)\end{array}$ & $\begin{array}{l}32 \\
(16.0 \%)\end{array}$ & $\begin{array}{l}78 \\
(39.0 \%)\end{array}$ & $\begin{array}{l}30 \\
(15.0 \%)\end{array}$ & $\begin{array}{l}15 \\
(7.5 \%)\end{array}$ & 662 & 3.31 & 10 \\
\hline 9. & $\begin{array}{l}\text { Use of indigenous } \\
\text { Knowledge }\end{array}$ & $\begin{array}{l}130 \\
(65.0 \%)\end{array}$ & $\begin{array}{l}70 \\
(35.0 \%)\end{array}$ & $\begin{array}{l}0 \\
(0 \%)\end{array}$ & $\begin{array}{l}0 \\
(0 \%)\end{array}$ & $\begin{array}{l}0 \\
(0 \%)\end{array}$ & 930 & 4.65 & 3 \\
\hline 10. & $\begin{array}{l}\text { save the } \\
\text { beneficial } \\
\text { microorganisms } \\
\text { in soil }\end{array}$ & $\begin{array}{l}101 \\
(50.5 \%)\end{array}$ & $\begin{array}{l}64 \\
(32.0 \%)\end{array}$ & $\begin{array}{l}35 \\
(17.5 \%)\end{array}$ & $\begin{array}{l}0 \\
(0 \%)\end{array}$ & $\begin{array}{l}0 \\
(0 \%)\end{array}$ & 866 & 4.33 & 5 \\
\hline
\end{tabular}


Table.2 Calculation of Garrett Value and Ranking

\begin{tabular}{|c|c|c|c|c|c|c|c|c|c|c|c|}
\hline \multirow[t]{2}{*}{ Statements } & \multicolumn{10}{|c|}{ Statement wise score as ranked by the respondents } & \multirow{2}{*}{$\begin{array}{l}\text { Toal } \\
\text { score }\end{array}$} \\
\hline & $1^{\text {st }}$ & $2^{\text {nd }}$ & $3^{\text {rd }}$ & $4^{\text {th }}$ & $5^{\text {th }}$ & $6^{\text {th }}$ & $7^{\text {th }}$ & $8^{\text {th }}$ & $9^{\text {th }}$ & $10^{\text {th }}$ & \\
\hline 1 & 5022 & 560 & 189 & 290 & 104 & 1786 & 126 & 1332 & 580 & 414 & 10403 \\
\hline 2 & 4941 & 2660 & 756 & 406 & 1508 & 846 & 504 & 296 & 348 & 216 & 12481 \\
\hline 3 & 1215 & 910 & 3024 & 2842 & 156 & 141 & 630 & 185 & 725 & 432 & 10260 \\
\hline 4 & 1782 & 1680 & 1575 & 2610 & 1820 & 329 & 504 & 777 & 232 & 18 & 11327 \\
\hline 5 & 486 & 700 & 3150 & 2204 & 624 & 987 & 1386 & 518 & 145 & 198 & 10398 \\
\hline 6 & 1215 & 910 & 2016 & 290 & 4004 & 611 & 84 & 777 & 232 & 36 & 10175 \\
\hline 7 & 972 & 350 & 1134 & 4176 & 2704 & 611 & 84 & 777 & 87 & 36 & 10931 \\
\hline 8 & 3240 & 5670 & 756 & 174 & 52 & 1081 & 185 & 185 & 348 & 378 & 12069 \\
\hline 9 & 648 & 4480 & 1701 & 2146 & 1144 & 564 & 378 & 222 & 232 & 126 & 11641 \\
\hline 10 & 405 & 1050 & 882 & 1392 & 1300 & 141 & 210 & 814 & 2117 & 252 & 8563 \\
\hline
\end{tabular}

Table.3 Constraints faced by the respondents $(n=200)$

\begin{tabular}{|c|l|c|c|}
\hline S. No. & \multicolumn{1}{|c|}{ Constraints } & $\begin{array}{l}\text { Mean } \\
\text { score }\end{array}$ & Rank \\
\hline $\mathbf{1}$ & Inadequate supporting infrastructure & 52.01 & VI \\
\hline $\mathbf{2}$ & Less availability and high inputs cost & 62.40 & I \\
\hline $\mathbf{3}$ & Poor credit facilities & 51.30 & VIII \\
\hline $\mathbf{4}$ & Marketing problem of produce & 56.63 & IV \\
\hline $\mathbf{5}$ & Lack of training & 51.99 & VII \\
\hline $\mathbf{6}$ & Lesser yield during initial years & 50.87 & IX \\
\hline $\mathbf{7}$ & Bulky nature of organic inputs & 54.65 & V \\
\hline $\mathbf{8}$ & $\begin{array}{l}\text { Insufficient premium price for organic } \\
\text { produce }\end{array}$ & 60.34 & II \\
\hline $\mathbf{9}$ & High risk and uncertainty of return & 58.20 & III \\
\hline $\mathbf{1 0}$ & $\begin{array}{l}\text { High cost and non-availability of } \\
\text { labor }\end{array}$ & $\mathbf{4 2 . 8 1}$ & $\mathbf{X}$ \\
\hline
\end{tabular}

Production of chemical free products ranked fourth perception of the organic agriculture with the weighted mean score 4.42 followed by save the beneficial microorganisms in soil which ranked with 4.33 weighted mean score. These results might be due to the fact that respondents gained knowledge through participation in various trainings on organic agriculture organized by TNAU,

With the weighed mean score 4.23, perception of organic farmers on production of quality produce got the position of sixth place in the perception statements. The probable reasons were long shelf life, colour and general appearance of the organic produce. Perception on sustain the farm productivity secured the with mean score of 4.10 ranked seventh position. Though less yield in initial years, the farmers experienced steady and increasing yield after a range of three to five years was the reason for this perception.

Fetching high price for the organic produce was identified as eighth ranked perception. 
Comparably organic products getting a considerable price in the market than the products of modern agriculture method.

In Ninth rank, reducing the high cost of Pesticides and Fertilizers was there with score of 3.57.Due to the non-use of pesticides, fertilizers and other chemical substances; a major portion of input cost was saved by the organic farmers. Instead, they used the Panchakavya, farmyard manures, green manures and bio inputs for which very less expenditure only incurred by the farmers.

The perception on difficult supervision and maintenance in organic agriculture was scored 3.31 and ranked last out of ten.

\section{Constraints of organic agriculture}

The constraints faced by the farmers are presented in the table. 3 with ranking by using the Garrett ranking technique.

Less availability of inputs and high cost was ranked as the first constraint with the mean score of 62.40 in the Garret ranking method. This result might be due to non availability of organic inputs such as bulk of FYM, bio fertilizers and other bio-inputs for pest and diseases management in the study area. This finding is conformity with the finding of Pankaj Kumar et al., (2018).

With the mean score of 60.34 , insufficient premium price for the organic produce was identified as the constraint which ranked as second (table.3).Even though the crops grown organically, there were no special marketing system or price fixing procedures for organic produce.

Third rank constraint identified was high risk and uncertainty of return as the constraint expressed by the respondents with 58.20 mean score. The probable reasons might be organic agriculture recorded lower yield in the initial stage irrespective of the crops where the chemicals not used for pest and disease management.

Marketing problem of organic produce was the fourth constraint derived in the ranking method. The lack of awareness about the value of organic produce is the main hurdles in selling organic products felt by the respondents.

Bulky nature of organic inputs (54.65) and inadequate supporting infrastructure (52.01) were placed in the rank of fifth and sixth respectively. Organic inputs like farmyard manure, compost, vermicompost, green manures and leaf manures were required in bulky in the organic agriculture; hence, the farmers expressed the constraints in availability of the bulky inputs. Farmers felt that lack of institutional supports for marketing and support price. This result of bulky nature of organic inputs is in conformity with the findings of Sivaraj, et al., (2017).

Lack of training was identified as the seventh ranked constraint. The probable reason might be due to unavailability of crop specific trainings on organic agriculture.

Poor credit facilities and lesser yield during the initial years ranked as eighth and ninth constraints with the mean score of 51.30.and 50.87 respectively. High cost and non availability of the labour was the tenth and least constraint identified in the rank order. This finding regarding non availability of labour is in contrast with the findings of Jaganathan et al., (2015).

In conclusion it could be observed from the study that less availability of inputs and high input cost and lesser yield were reported as the constraints. Hence, government should 
take steps to support the organic farmers in the initial stage of starting organic agriculture in terms of providing subsides etc to motivate the farmers to go for organic agriculture and compensate the yield reduction in the initial stages. Further, exclusive market and remunerative price supports for organic produce need to be established for successful organic agriculture.

\section{Acknowledgement}

Author would like to express sincere gratitude to Tamil Nadu Agricultural University to given an opportunity to study Ph.D degree and my sincere thanks to authorities of my working organization IGNOU for granted study leave to pursue the Ph.D in regular mode.

\section{References}

Aulakh, C.S; Singh, Surjitwalia. S.S.Gurpreet kaur (2009) farmers perception s on organic farming inpunjab Journal of Research, Punjab Agricultural University vol46 no2 pp 9-13.

Azamanand SagarMaitra. Organic agriculture prospects, problems and constraints pdfs -sematischolar. org 9 www.aditert.net. news letter organic agriculture.

IFOAM \& FIBL (2006). The world of organic agriculture.Statistics and emerging trends

2006.IFOAM,FiBL,Frick.http://orgprint s.org/5161/01/youssefi-2006.overview pdf.

Jaganathan,et.al.,(2015). Analysis of organic farming practices in cocoa in india.Journal of plantation crops, 2015 , 43(2), 131-138

Organic Agriculture Training Booklet (2018). Tamil version, Dept. of Sustainable Organic Agriculture, TNAU, Coimbatore.

Pankaj Kumar et al.(2018).Impact of Training Programme on Adoption of organic farming Practices.

Supe,S.V. 1969. Factors Related to Different Degrees of Rationality in Decision making among farmers. Unpub. Ph.D (Ag.) Thesis. IARI. Newdelhi.

Sivaraj P, et al., (2017). Constraints and suggestions of certified organic farmers in practicing organic farming in practicing organic farming in western zone of tamilnadu, india.

Suryatapa Das et.al., (2020). Organic farming in India: a vision towards a healthy nation, Food Quality and safety, 2020, Vol.4, No.2, 69-76.

Willer and Lernoud (2019). The world of organic agriculture statistics and emerging trends 2019, IFOAM organic international, P.191, RIOA.

\section{How to cite this article:}

Namboothiripad, P., J. Pushpa, K. Mahandrakumar, J. S. Amarnath and Prabakaran, 2021. An Impact Study-Perception and Constraints of Organic Agriculture Farmers. Int.J.Curr.Microbiol.App.Sci. 10(01): 2450-2455. doi: https://doi.org/10.20546/ijcmas.2021.1001.283 